\title{
REMARKS ON COLLECTING AT LIGHT, WITH A LIST OF THE COLEOPTERA TAKEN.
}

\author{
By C. A. Frost, \\ Framingham, Mass.
}

After I had settled in South Framingham, it was not long before I discovered that I had selected a favorable room for my "bugden," since moths and other insects soon began to visit me by way of the windows while at work on my collection during the summer evenings.

The house is so situated that from my room, an attic one on the third floor, one looks out over gardens, yards, and shade trees, toward the west. It was formerly shaded by several European spruces and a large elm, but one of the spruces is almost dead and the elm has been cut down at the request of a "back-to-the-soil" enthusiast whose crop of weeds has probably furnished me with some fine micro-lepidoptera. The afternoon sun beats in the two windows and, in spite of the closed blinds, renders the room uninhabitable to anyone but a "bug-catching crank" long after the sun has set. The insinuations in regard to my mental condition become more emphatic as the summer progresses and the heat drives the rest of the household to the piazza, while I insist on retiring to my room for the evening collecting. The heat caused me much trouble with my point mounting so that I discontinued the use of shellac for some time and adopted an English cement which sets very quickly and does not soften. I have since concluded that it was a poor quality of shellac which softened with the heat and allowed the insects to drop off or twist about. When I returned from a vacation trip to Colorado after the extremely hot period of July, 1911, to find my new boxes stuck together and a penholder more than half buried in a cake of paraffine on my table-I was mighty glad I went. Dozens of my shellac-mounted specimens have had to be remounted as a result of that summer's heat.

The town has grown very rapidly since I came here in 1904 and is now an embryo city with houses springing up on every vacant lot, so that I suspect a falling off in the number of specimens that 
come to my light. I have used an ordinary kerosene lamp with a reflector, sometimes turned to throw the light out of the window, but more often to reflect onto my work; and the insects seem to come in just as readily. I have also tried setting the lamp on a chair before the window with a sheet of glazed paper hanging over the back behind the lamp, with some success. Nothing comes to light on moonlight evenings and a dark, muggy night is, of course, the best. I have taken many Lepidoptera during a pouring rain.

The most abundant species of moths belong to the genera Leucania, Hadena, Mamestra, Feltia, and Crambus. Certain Geometridæ, as Xanthorhoea ferrugata, Gypsochroa designata, and Hydriomena multiferata, have been common in the past but they have almost disappeared during the last few years.

It is a matter of much regret that $I$ have not kept a complete record of the many species of Lepidoptera taken on the table and the walls of my room. Many of the species immediately hide behind the boxes and in obscure nooks and appear next morning on the screens or between the curtain and the glass of the windows. Others are never seen until picked up dead on the floor. Nearly all the specimens fly about the light for a time and then, especially the micros, settle down on the table or fly to the ceiling to remain until disturbed. A favorite resting place for the species of Hadena and Leucania is the dark varnished door to the hall, perhaps on account of the draft through the crack next the jamb.

For some time I used to identify the moths as they came in, and then paper at once or reserve for mounting the next morning, but one evening a robust Hadena entered an open double box of Lepidoptera and quietly remained there until the box was shut up and replaced on the shelf. Some days later on opening the box I found that its work had sufficiently identified it as devastatrix.

I have generally collected from dark to midnight but have remained as late as 2 a. m. on especially favorable nights. The specimens come intermittently -in bunches best expresses itand sometimes a dozen specimens will be bumping about the room, then hardly one for half an hour or so. On some evenings the ceilings will be dotted with hundreds of minute Diptera and Hemiptera, and yet it is seldom that a mosquito finds its way in. I once counted 94 specimens of small Diptera stuck on a quadrant of the base of the lamp, a total of 376 for the whole base. I thought it a hopeless task to count those on the table. 
Late in the summer a species of lace-winged fly (Chrysopa) becomes common and I was once surprised to receive a sharp bite on the arm from one of these delicate insects.

The largest insects that have come in were Telea polyphemus and Prionus pocularis.

The list of Coleoptera is very small compared with the species of Lepidoptera that have been taken, but it may be of interest to record them for many of the species (as Macrobasis torsa and Liopus alpha) must have flown at least a mile from their breeding places into the thickly settled part of the town.

\section{List of Coleoptera Taken at Light.}

Bembidium variegatum Say, July 28, 1913. Amara apricarius Payk., August 23, 1910. Platynus Sp? (near moerens Dej.), June 29, 1913. Platynus aeruginosus Dej., May 27, 1908. Lebia atriventris Say, May 28 and June 19, 1908. Lebia viridipennis Dej. June 19, 1908. Lebia ornata Say, July 4, 1909. Lebia scapularis Dej., September 4, 1910. Pinacodera platicollis Say, October 1, 1910. Chlaenius pennsylvanicus Say, May 24, 1908. Chlaenius tricolor Dej., May 24, 1908. Harpalus pennsylvanicus DeG., June 28, 1908; August 13, 1912. Harpalus erythropus Dej., July 24, 1911. Stenolophus ochropezus Say, May 24 and 27, 1908; May 16, 1909; July 1 and August 4, 1910; July 31, 1911; April 21, 1912; July 28, 1913. Agonoderus pallipes Fab., July 1, 1907; July 2 and 28, 1913, and many others not recorded. Agonoderus lineola Fab., May 24, 1908; July 18, 1909. Anisodactylus terminatus Say, July 28, 1913. Anisodactylus sericeus Harr., May 27, 1908.

Hydrocharis obtusatus Say, July 29, 1913. Philhydrus ochraceus Mels., July 28, 1913.

Necrophorus americanus Oliv., May 31, 1908. Necrophorus orbicollis Say, October 4, 1910. Agathidium oniscoides Beauv., May 27, 1908.

Oxylelus sculptilis Grav., May 24, 1908. Acylomus ergoti Casey, June 8, 1908. Hippodamia 13-punctata L., August 23, 1912. Adalia bipunctata L., July 7, 1908. Henoticus serratus Gyll., August 8, 1913. Lathropus vernalis Lec., July 4, 1908. Litargus sexpunctatus Say, July 26, 1912. Typhơa fumata L., May 28, 1908; July 21, 1911; August 21, 1912 (two specimens). 
Cryptarcha ampla Er., June 23, 1904. Melanopthalmus obtusa Lec., April 5, 1910; September 8, 1911. Melanopthalmus distinguenda Com., May 29 and July 4, 1908. Prionocyphon discoideus Say. (?), July 5, 1904.

Entomophthalmus rufiolus Lec., June 28, 1910. Melanotus communis Gyll., May 24, 1908; May 6, 1913. Melanotus trapezoideus Lec., July 15, 1911. Melanotus sagittarius Lec., May 30, 1908. Limonius basillaris Say, July 15, 1911. Athous cucullatus Say, June 27, 1908. Asaphes memnonius Hbst., June 27 and July 4, 1908.

Podabrus tricostatus Say, June 9, 1910. Podabrus rugulosus Lec., June 27, 1908; June 30, 1910; June 29, 1913. Podabrus basillaris Say, May 29 and 31, 1908; June 4, 1913. Podabrus simplex Coup., May 29, 1908; June 3, 1912. Silis percomis Say, May 23, 1911. Telephorus bilineatus Say, May 25, 1908.

Cregya oculata Say, August 5, 1910 (two specimens). Ernobius mollis L., May 29, 1908; July 2, 1913. Lucanus dama Thunb. Several times, no record at hand.

Trox unistriatus Beauv., August 10, 1907. Trox scaber L., May 29, 1912. Dichelonycha elongata Fab., June 4, 1912. Dichelonycha albicollis Burm., May 25, 1910. Dichelonycha diluta Fall (?), June 1, 1912. Serica vespertina Gyll., June 19, 1908. Serica sericea Ill., June 9, 1910. Diplotaxis sordida Say, July 29, 1913. Diplotaxis atlantis Fall, May 25, 1908. Lachnosterna fusca Fröl., May 19, 1907; May 7, 1910; and many other records. Lachnosterna nova Smith, June 22, 1908; May 25, 1910; May 25, 1912. Lachnosterna hirticula Knoch, May 25 and 29, 1910; one of the most common visitors. Pelidnota punctata L., July 17, 1911; August 9, 1912. Ligyrus relictus Say, September 7, 1910 and several other records.

Orthosoma brunneum Forst., June 28, 1913. Prionus pocularis Dalm., July 30, 1911. Criocephalus agrestis Kirb., July, 1913. Elaphidion villosum Fab., July 18, 1909; May 6, $1913 . \quad$ Xylotrechus colonus Fab., July 14, 1912. Monohammus titillator Fab., July 29, 1913. Monohammus confusor Kirby, July 23, 1913 (male and female). Liopus alpha Say, July 10, 1909; June 25 and 30, 1913.

Gastroidea polygoni L., July 6, 1908. Diabrotica vittata Fab., August 25, 1910 and many other records. Galerucella luteola 
Muls., August 13, 1912, and many other records. Oedionychis limbalis Melsh., May 3, 1913.

Tenebrio molitor L., July 6, 1908. Strongylium tenuicolle Say, June 27, 1908. Hymenorus discretus Casey, June 28, 1908; August 24, 1909; June 25, 1913. Hymenorus niger Melsh., June 20, 22, and 24, 1908. Hymenorus melsheimeri Casey, August 4, 1910. Mycetochares megalops Casey, May 30, 1911. Carebara longula Lec., July 10, 1907. Orchesia castanea Melsh., August 13, 1912. Salpingus virescens Lec., August 12, 1912. Capnochroa fuliginosa Melsh., July 17, 1912. Glipodes sericans Lec., August 4, 1910. Mordellistena dimidiata Helm. July 4, 1908. Notoxus anchora Hentz, July 4, 1908; June 28, 1910. Notoxus monodon Fab., August 17, 1911. Dendroides concolor Newm., June 3, 1912. Macrobasis torsa Lec., June 15, 1908.

Hylobius pales Hbst., May 24, 1908; April 17, 1910. Pachylobius picivorus Germ., August 14 and September 3, 1910. Conotrachelus nenuphar Hbst., May 30, 1908. Conotrachelus elegans Say, May 27, 1908. Cryptorhynchus bisignatus Say, June 29, 1913. Balaninus uniformis Lec., August 19 and September 5, 1912. Crypturgus atomus Lec., August 5, 1910. Cratoparis lunatus Fab., July 31, 1911.

\title{
AN IMPROVED COLLECTING BOTTLE.
}

\author{
By C. N. Ainslie,
}

U. S. Department of Agriculture, Bureau of Entomology, Cereal and Forage Insect Investigations.

In common with many other entomologists, I have been greatly annoyed by the condensing of the moisture on the inside of my collecting bottle. I notice that some entomologists make a hole in the cork and place a lump of cyanide therein, but in my experience it is only a matter of a few days until the cork becomes damp and sticky and unfit for use, especially in rainy weather.

The writer has recently adopted the plan of sinking a $9 \times 36 \mathrm{~mm}$. shell vial in the cork, with the mouth of the vial opening into a larger bottle or tube, whichever may be used. If these $9 \times 36 \mathrm{~mm}$. vials are too long they may be cut off so that the opening will be flush with the surface of the cork, although I prefer to have them 

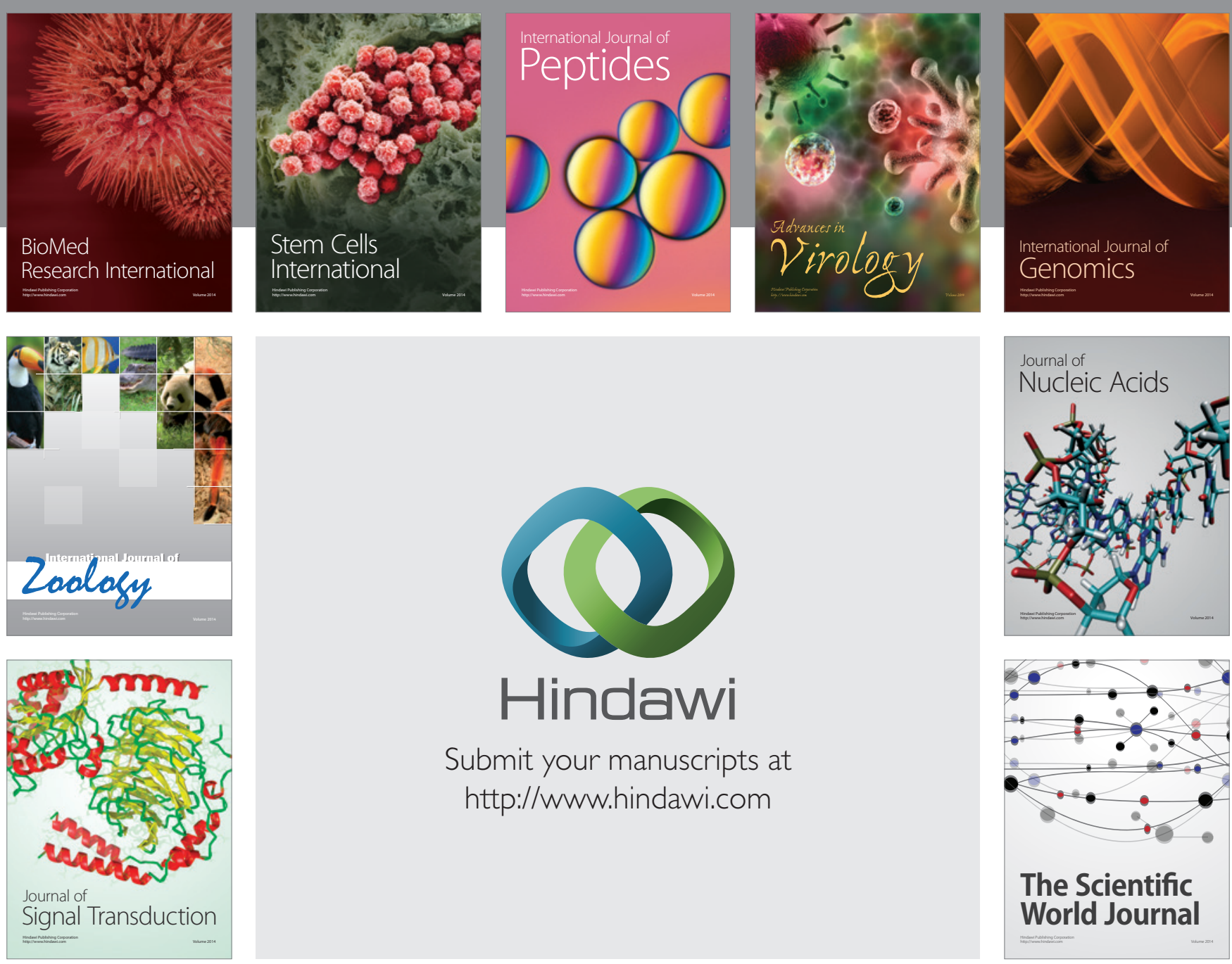

Submit your manuscripts at

http://www.hindawi.com
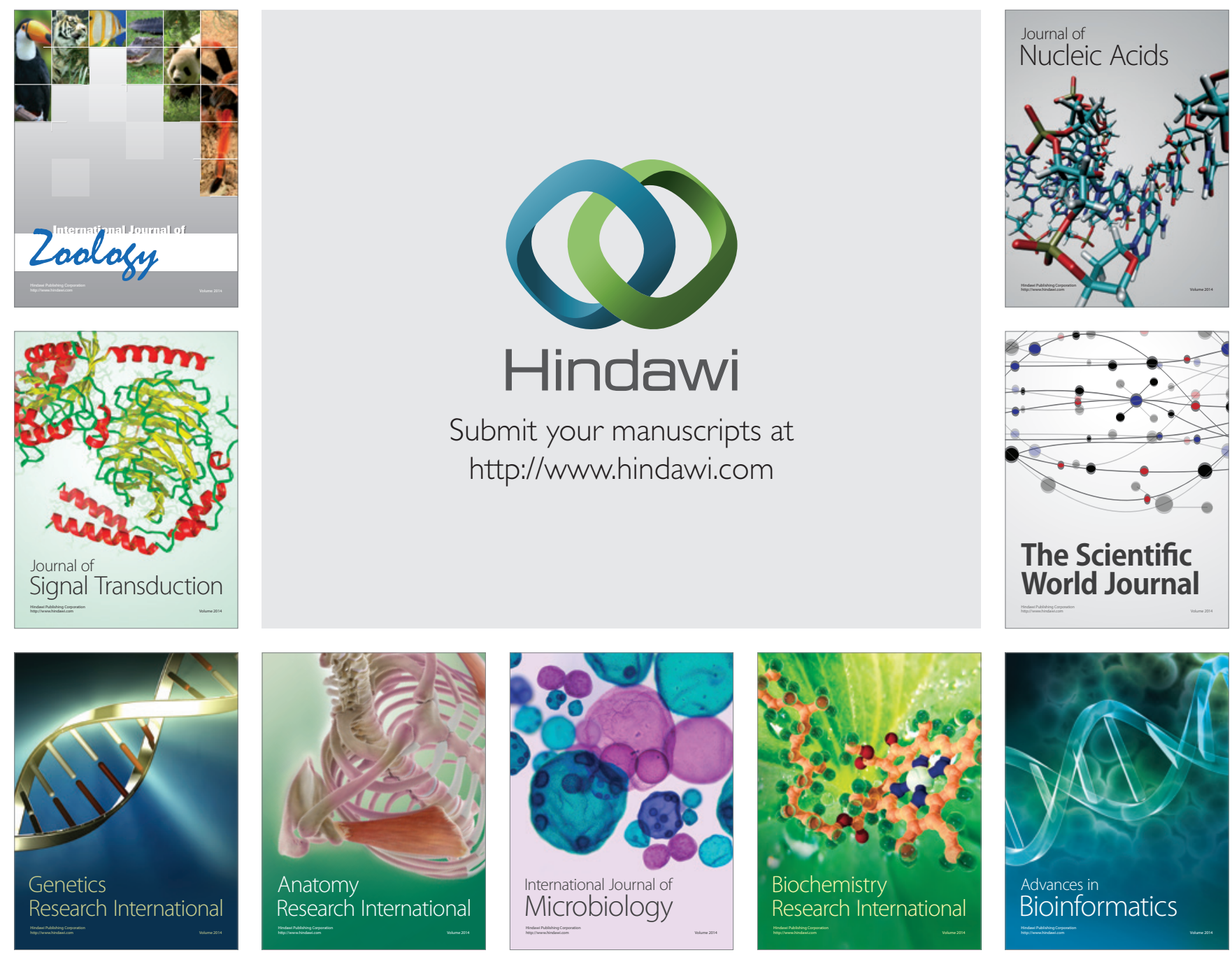

The Scientific World Journal
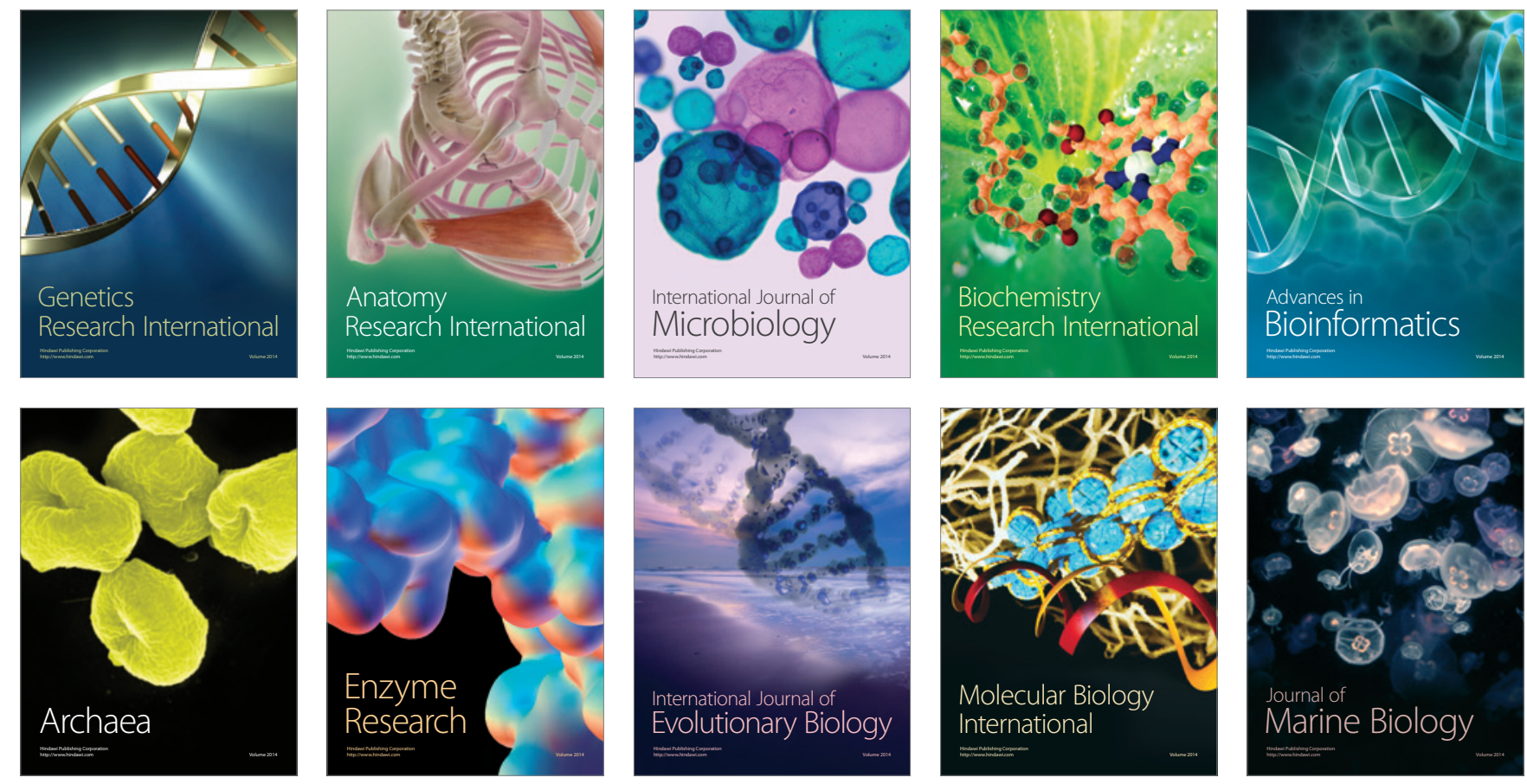